\title{
KONSUMSI SUSU FORMULA TERHADAP KEJADIAN KARIES GIGI PADA ANAK PRASEKOLAH DI PGTKIT ALHAMDULILLAH BANTUL YOGYAKARTA
}

\author{
Imroatul Azizah ${ }^{1}$ dan Dwi Yulinda ${ }^{2}$ \\ ${ }^{1}$ Prodi Kebidanan (D-3) Fakultas Kesehatan Universitas Jenderal Achmad Yani Yogayakarta, Indonesia \\ ${ }^{2}$ Prodi Kebidanan (S-1) Fakultas Kesehatan Universitas Jenderal Achmad Yani Yogayakarta, Indonesia
}

\begin{abstract}
Abstrak
Pemberian susu formula dianggap sebagai pengganti air susu ibu yang bertujuan untuk memenuhi kebutuhan nutrisi bagi pertumbuhan dan perkembangan anak. Kandungan yang ada dalam susu formula sering diabaikan terutama kadnungan sukrosa atau gula pada masing-masing merk. Tingginya kadar gula akan menurunkan $\mathrm{pH}$ plak dengan cepat sampai pada level yang dapat menyebabkan demineralisasi email sehingga terjadi kerusakan pada gigi. Selain itu defisiensi beberapa vitamin dan mineral juga mendorong terjadinya karies pada gigi seperti defisiensi vitamin A, B, C, dan D, kalsium, fosfor fluor dan zinc. Anak-anak di bawah 12 tahun merupakan kelompok rentan terjadinya masalah pada gigi berupa gigi berlubang. Penelitian ini bertujuan untuk mengetahui hubungan antara konsumsi susu formula dengan kejadian karies gigi pada anak prasekolah. Metode yang digunakan pada penelitian ini merupakan penelitian deskriptif kuantitatif dengan pendekatan cross sectional dan teknik pengambilan sampel secara acak. Analisa data mengunakan Chi-Square. Hasil yang diperoleh sebagian besar responden dengan jenis kelamin laki-laki 53,3\%, usia 3-5 tahun 54,4\%, 70,2\% mengalami karies gigi, dengan jumlah konsumsi susu formula $\leq 3 \mathrm{kali} /$ hari 50,9\%. Chi-Square menghasilkan nilai signifikansi sebesar 0,005 nilai p-value yang lebih kecil dari 0,05 menunjukkan bahwa ada hubungan antara konsumsi susu formula dengan kejadian karies gigi di PG-TKIT. Di hari pemberian minuman seperti susu formula yang hampir semua merk mengandung sukrosa dan oral-higiene yang salah merupakan penyebab terjadinya karies gigi. Hal ini dikarenakan sukrosa merupakan gula yang paling kariogenik (menyebabkan gigi berlubang), ditambah waktu kebiasaan gosok gigi yang salah. Di perlukan penyuluhan kesehatan tentang konsumsi susu formula serta kebiasaan menggosok gigi kepada orang tua sehingga mengindari terjadinya karies gigi pada anak.
\end{abstract}

Kata Kunci : Susu formula ; Karies gigi, ; Prasekolah

\section{CONSUMTION OF FORMULA MILK TO CARIES DENTIS IN PRESCHOOL CHILDREN IN PGTKIT ALHAMDULILLAH BANTUL YOGYAKARTA}

\begin{abstract}
Introduction: Provision of formula milk as a substitute for breast milk is needed to meet the nutritional needs for growth and development of children. The content in formula milk is often overlooked in terms of sucrose or sugar in each brand. High levels of sugar will reduce $\mathrm{pH}$ quickly to a level that can cause enamel demineralization resulting in tooth decay. Besides deficiencies of some vitamins and minerals are also supported by dental caries such as deficiencies of vitamins A, B, C and D, calcium, fluorine phosphorus and zinc. Children under 12 years are a group vulnerable to problems with teeth consisting of cavities. Objective: This research is to study the relationship between consumption of formula milk and the incidence of dental caries in preschool children

Method: This is a quantitative descriptive study with cross sectional research and random sampling techniques. Data analysis using Chi-Square Results: Most respondents were male 53.3\%, 3-5 years old 54.4\%, 70.2\% used dental caries, with the consumption of formula milk kali3 times / day 50.9\%. Chi-Square produced a significance value of $0.005 \mathrm{p}$-value less than 0.05 between the consumption of formula milk and the incidence of dental caries in PG-TKIT Alhamdulilah. The provision of drinks such as formula milk that most contain sucrose and oralhygiene which is the cause of the use of dental caries. This is because sucrose is the most cariogenic sugar (causing cavities), plus the time of the wrong tooth brushing habit. In need of health education about the consumption of formula milk and the habit of brushing teeth to parents so as to avoid dental caries in children.
\end{abstract}

Keywords:. Formula milk, caries dentis, preschool children 


\section{Pendahuluan}

Karies merupakan suatu penyakit jaringan keras gigi yaitu email, dentin dan sementum yang disebabkan oleh aktivitas jasad renik dalam suatu karbohidrat yang dapat diragikan. Menurut data dari pengurus besar PDGI (Persatuan Dokter Gigi Indonesia) menyebutkan bahwa sedikitnya 89\% penderita gigi berlubang adalah anak-anak usia dibawah 12 tahun. Makanan kariogenik merupakan faktor penyebab utama terjadinya karies gigi bersamasama dengan faktor mikroorganisme, gigi (host) dan waktu. Makanan ini bersifat PH rendah, mengandung gula yang tinggi dan lengket. Karbohidrat adalah bahan yang sangat kariogenik. Gula yang terolah seperti glukosa dan terutama sekali sukrosa sangat berperan dalam pembentukan karies dengan merubah keasaman atau $\mathrm{pH}$ saliva dibawah 5.5 secara drastis sehingga memudahkan terjadinya demineralisasi. Gula sukrosa mempercepat pertumbuhan mikroorganisme asidogenik dibanding jenis karbohidrat lain. ${ }^{12,14}$ Menurut penelitian Purwaningsih A (2016) semakin tinggi (>3 kali/hari) frekuensi pemberian susu formula maka semakin tinggi risiko kejadian karies. Hasil studi pendahuluan yang dilakukan di PG-TKIT Alhamdulillah Bantul, 10 anak mengalami karies pada gigi dan mengkonsumsi susu formula dan ada 1 anak yang mengalami karies gigi tetapi tidak mengkonsumsi susu formula. Berdasarkan hal tersebut, maka penting dilakukan penelitian tentang Hubungan antara konsumsi susu formula dan gosok gigi dengan kejadian karies gigi pada anak-anak di PG-TKIT Alhamdulilah Bantul Yogyakarta Tahun 2018.

\section{Metode}

Penelitian ini dilakukan secara deskriptif kuantitaif dengan pendekatan cross sectional. Penelitian ini dilakukan pada anak balita dan pra sekolah. Tempat penelitian ini di PG-TKIT Alhamdulilah Bantul Yogyakarta pada bulan Mei-September 2018 dengan pengambilan sampel secara random. Penelitian ini telah mendapatkkan persetujuan dari Komite Etik Stikes Achmad Yani Yogyakarta.

\section{Hasil Penelitian dan Pembahasan}

Penelitian ini dilakukan pada responden dengan jumlah 114 yang kemudian akan dideskripsikan berdasarakan jenis kelamin, umur dan kejadian karies.

Tabel 1. Karakteristik Responden

\begin{tabular}{lcc}
\hline Katagori & Frekuensi & Persentase (\%) \\
\hline Jenis Kelamin & & \\
Laki-laki & 61 & $53,5 \%$ \\
Perempuan & 53 & $45,6 \%$ \\
\hline Umur & & $54,4 \%$ \\
$3-5$ tahun & 62 & $45,6 \%$ \\
$>5$ tahun & 52 & 100
\end{tabular}

Berdasarkan tabel 1. Karakteristik responden berdasarkan jenis kelamin bahwa sebagian besar responden dalam kategori laki-laki yaitu sebanyak 61 responden (53.3\%) Sedangkan berdasarkan usia bahwa sebagian besar responden dalam kategori usia 3-5 tahun yaitu sebanyak 62 responden (54.4\%). 
Tabel 2. Distribusi frekuensi kejadian karies dan konsumsi susu formula

\begin{tabular}{lcc}
\hline & Frekuensi & Persentase (\%) \\
\hline Karies dentis & & \\
Ya & 80 & 70.2 \\
Tidak & 34 & 29.8 \\
Konsumsi susu formula & & \\
$\leq 3$ kali & 58 & 50,9 \\
$>3$ kali & 56 & 49,1 \\
\hline Total & 114 & 100 \\
\hline
\end{tabular}

Berdasarkan tabel 1. Diatas kejadian karies bahwa sebagian besar responden mengalami karies gigi yaitu sebanyak 80 responden dengan persentase $70.2 \%$ dan frekuensi minum susu bahwa sebagian besar responden mengonsumsi susu $<3$ kali dalam sehari yaitu sebanyak 58 responden dengan persentase $50.9 \%$.

Hasil analisis dan pengujian hipotesis dapat disajikan berupa grafik atau tabel untuk memperjelas secara verbal. Tabel dan gambar dapat menggunakan angka 1,2,3, dan seterusnya. Jumlah tabel dan gambar maksimal 5. Judul tabel berada diatas, sedangkan judul gambar ada di bawah.

Tabel 3. Tabulasi Silang Antara Konsumsi Susu Formula dengan Kejadian Karies gigi

\begin{tabular}{|c|c|c|c|c|c|c|}
\hline & & & & Karie & & Total \\
\hline & & & & $\mathrm{Ya}$ & Tidak & \\
\hline Konsumsi & Susu & $\leq 3 \mathrm{kali}$ & $\mathrm{f}$ & 34 & 24 & 58 \\
\hline Formula & & & $\%$ & 58.6 & 41.4 & \\
\hline & & $>3$ kali & $\mathrm{f}$ & 46 & 10 & 56 \\
\hline & & & $\%$ & 82.1 & 17.9 & \\
\hline & & & $\mathrm{f}$ & 80 & 34 & 114 \\
\hline & & & $\%$ & 70.2 & 29.8 & 100 \\
\hline
\end{tabular}

Berdasarkan tabel 2. diatas diketahui bahwa konsumsi susu formula lebih dari 3 kali dalam sehari menyebabkan kejadian karies gigi pada 46 responden atau sebesar 82.1\%, dan 10 responden tidak mengalami karies gigi atau sebesar $17.9 \%$.

Hasil pengujian menggunakan uji Chi-Square menghasilkan nilai signifikansi sebesar 0,005 nilai p-value yang lebih kecil dari 0,05 menunjukkan bahwa ada hubungan antara konsumsi susu formula dengan kejadian karies gigi di GP-TKIT Alhamdulilah.

Berdasarkan hasil penelitian yang disajikan dalam diagram 1 dan 2 yang berhubungan dengan karakteristik responden didapatkan hasil bahwa sebagian besar responden dalam kategori berjenis kelamin lakilaki yaitu sebanya 61 responden $(53.5 \%)$ dan usia terbanyak dalam kategori lebih dari dari 5 tahun yaitu sebanyak 62 responden (54.4\%). Secara teori karakteristik ini tidak berpengaruh secara langsung terhadap kejadian karies gigi namun merupakan faktor risiko. Studi epidemiologi menunjukkan bahwa dengan bertambahnya usia maka akan meningkatkan prevalensi kejadian karies gigi. Hal ini dikarekan adanya erupsi pada gigi. Pada anak-anak memiliki risiko yang tinggi sebab gigi anak-anak baru mengalami erupsi. Decayed missing filled tooth (DMFT) pada anak wanita lebih tinggi daripada pada anak laki-laki, akan tetapi oral hygiene yang baik pada wanita menyebabkan bertahannya gigi daripada laki-laki. ${ }^{5}$

Hasil penelitian pada tabel 1 menunjukkan bahwa kejadian karies gigi di PG-TKIT Alhamdullilah sangat tinggi yaitu sebanyak 80 responden atau $70.2 \%$. Kejadian karies gigi pada anak tidak terlepas dari peran orang tua yang peduli tentang kesehatan gigi dan mulut terutama dalam menggosok gigi secara teratur. Dalam penelitian Husna tentang peran orangtua dan perilaku anak dalam menyikat gigi dengan kejadian karies anak menunjukkan 
bahwa merupakan masa di mana anak-anak akan lebih sering mengkonsumsi berbagai jenis makanan karbohidrat yang manis seperti cokelat, permen, kue-keu, dan makanan lainnya yang berbentuk tepung atau caiaran yang bersifat lengket dan mudah hancur didalam mulut sehingga dapat menyebebkan karies dan jika hal ini tidak di imbangi dengan pengetahuan orangtua yang baik dalam membiasakan prilaku untuk mnggosok gigi secara teratur dan benar maka karies pada gigi akan mudah terbentuk. ${ }^{3,6}$

Karies gigi merupakan penyakit infeksi yang disebabkan oleh demineralisasi email, dentin dan sementum karena konsumsi makanan yang kariogenik terutama karbohidrat. Salah satu contoh karbohidrat sederhana adalah laktosa (gula susu). Terjadinya karies gigi akibat Gula yang dikonsumsi akan dimetabolisme sedemikian rupa sehingga terbentuk polisakarida yang memungkinkan bakteri melekat pada permukaan gigi, selain itu juga akan menyediakan cadangan energi bagi metabolisme karies selanjutnya serta bagi perkembangbiakan bateri kariogenik. ${ }^{4,7,12}$ Hasil pada tabel 1 menunjukkan bahwa yang mengonsumsi susu formula $\leq 3$ kali sehari sebanyak $58(50,9)$ dan yang mengonsumsi susu formula $>3$ kali sehari sebanyak $56(49,1 \%)$. Tabel 2. yang merupakan tabulasi silang antara konsumsi susu formula dengan kejadian karies gigi menunjukkan bahwa kejadian karies gigi terbesar pada kelompok anak yang minum susu lebih dari 3 kali dalam sehari. Dalam tabel tersebut terlihat ternyata persentase kejadian karies gigi pada anak terbanyak pada anak dengan frekuensi minum susu $>3 x$ sehari yaitu sebanyak $82.1 \%$ dari 56 anak. Sedang pada anak $\leq 3 x$ sehari presentase karies gigi $58.6 \%$ dari 58 anak. Hal ini berarti semakin sering minum susu maka kejadian karies gigi makin banyak peluang terjadinya. ${ }^{9}{ }^{11}$ Hasil penelitian ini sejalan dengan penelitian yang dilakukan oleh Astuti dkk di TK Tunas Wijaya yang menyimpulkan bahwa rendahnya konsumsi karbohidrat berpengaruh terhadap rendahnya karies gigi. ${ }^{3}$

Pemberian minuman seperti susu formula yang hampir semua merk mengandung sukrosa dan oralhigiene yang salah merupakan penyebab terjadinya karies gigi. Hal ini dikarenakan sukrosa merupakan gula yang paling kariogenik (menyebabkan gigi berlubang), ditambah waktu kebiasaan gosok gigi yang salah yaitu sesudah mandi. Hal ini karena sesudah mandi anak akan makan yang kemudian tidak membersihkan giginya lagi sehingga banyak sisa makanan yang terselip diantara kedua gigi dan di bagian dataran pengunyah atau setelah mandi anak akan minum susu sehingga sukrosa akan menempel pada email gigi sehingga menyebabkan gigi berlubang.Sehingga secara teori dapat disimpulkan bahwa jika mengonsumsi susu formula dapat mempengaruhi kejadian karies. ${ }^{5,16}$

\section{Kesimpulan}

Terdapat hubungan yang signifikan antara penggunaan susu formula dengan kejadian karies gigi pada anakanak di PG-TKIT Alhamdulilah Bantul Yogyakarta Tahun 2018 dengan nilai signifikan 0.005.

\section{Daftar Pustaka}

1. Almatsier S. 2006. Prinsip Dasar Ilmu Gizi. Jakarta: PT Garamedia Pustaka Utama

2. Arikunto, S. 2010. Prosedur Penelitian Suatu Pendekatan Praktik. Jakarta: Rineka Cipta

3. Astuti PAE, Prasetya MA, Sukrama IDM. 2017. Hubungan Tingkat Konsumsi Karbohidrat dengan Kejadian Karies Pada Anak Taman Kanak-Kanak Tunas Wijaya Desa Tonja Kecamatan Denpasar Utara. Bali Dental Journal. Vol 1(2):39-45

4. Bakar, A. 2012. Kedokteran Gigi Klinis. Edisi 2. Yogyakarta: Quantum Sinergis Media

5. Brown JP and Dodds MWJ. 2008. Prevention Strategies for dental Caries. In: Cappelli DP and Mobley CC. Preventionand Clinical Oral Health Care. Missuori : Mosby Elsevier

6. BS Suresh, TL Ravishankar, TRChaitra, AK Mohapatra, V Gupta. 2010. Mother's knowledge abut preschool child's oral health. Journal of Indian Pedodontics and Preventive Dentistry. Vol 4(28):282-7

7. Husna A. 2016. Peran Orangtua dan Prilaku Anak Dalam Menyikat Gigi Dengan Kejadian Karies Anak. Jurnal Vokasi Kesehatan. Vol 2(1):17-23 
8. Kemenkes RI. 2013. Profil Kesehatan Yogyakarta Tahun 2013. Yogyakarta

9. Norfai., Rahman, E. 2017. Hubungan pengetahuan dan kebiasaan menggosok gigi dengan kejadian karies gigi di SDI Darl Mu;minin Banjarmasin. Dinamika Kesehatan. Vol 8(1): 212-218

10. Notoatmodjo, S. 2012, Promosi Kesehatan dan Perilaku Kesehatan. Jakarta: Rineka Cipta

11. Nurhidayah, E. Diana, S. 2013. Hubungan antara penggunaan dot dalam pemberian susu formula dengan kejadian caries gigi balita usia 4-5 tahun di TK Tarbiyatush Shibayan Desa Gayaman Mojoannyar Mojokerto. Hospital Majapahit. Vol5(1):48-60

12. Panggabean SP., 2003. Pencegahan Karies Gigi Dengan Imunisasi. Dentika Dental Jurnal 2003

13. Purwaningsih, A. 2016. Pengaruh Pemberian Susu Formula Menggunakan Botol Susu (Dot) Terhadap Kejadian Rampan Karies Pada Anak Pra Sekolah Di Kelurahan Pabelan. Naskah Publikasi Skripsi. Universitas Muhammadiyah Surakarta

14. Ramayanti S dan Purnakarya I., 2013. Peran Makanan Terhadap Kejadian Karies gigi. Jurnal Kesehatan Masyarakat. Vol 7(2):89-93

15. Radler DR, Touger-Decker R. 2008. Nutrition for Oral and Dental Health. In:Mahan LK, Escott-Stump S. Krause's Food\&Nutrition Teraphy, St Louis : Saunders Elsevie.

16. Sariningsih E. 2014. Merawat Gigi Anak Sejak Dini. Gramedia: Jakarta 